\title{
Education of Logopedists or Speech-Language Pathologists in Bulgaria, Greece, Macedonia, Poland and Russia
}

\author{
Dobrinka Georgieva \\ Department of Logopedics, South-West University, Blagoevgrad, Bulgaria
}

\author{
Key Words \\ Logopedics • Training programs • Bulgaria • Greece • \\ Macedonia $\cdot$ Poland $\cdot$ Russian Federation
}

\begin{abstract}
This article provides an overview of student training programs in logopedics in Bulgaria, Greece, Macedonia, Poland and the Russian Federation. The data were collected using a special questionnaire developed by Söderpalm in 2006 and supplemented by the author. Bachelor's, master's and PhD programs in the field of pure logopedics no longer exist in some countries. In other locations, logopedics is included as a part of special education student training. In all cases, student education in logopedics is centralized in the universities. Educational programs are accredited by national agencies for accreditation or evaluation or by the respective Ministries of Education.

Copyright $\odot 2010$ S. Karger AG, Basel
\end{abstract}

\section{Introduction}

Logopedics is a young interdisciplinary area of study in the countries sampled for this study, i.e. Bulgaria, Greece, Macedonia, Poland and the Russian Federation. The procedures and possibilities for obtaining a degree in logopedics or the qualification to practice logopedics have varied over the years and from country to country. This article presents an overview of the educational training systems in logopedics. The countries sampled differ considerably in size and population: Macedonia has 2,114,550 inhabitants, Bulgaria 7,917,855, Greece 11,216,708, Poland 38,576,000 and Russia 142,000,838.

\section{Method}

Six leading university professors of logopedics (1 each from Bulgaria, Macedonia, Poland and Russia, and 2 from Greece) were solicited to provide an overview of the logopedics programs at their institutions. Each of these specialists was further asked to complete a 17-item questionnaire based on Söderpalm [1] (see Appendix). The data from these overviews and the questionnaire responses serve as the primary sources for this report.

\section{Results}

Table 1 summarizes the characteristics of the programs. Table 2 shows the qualifications of logopedists in the 5 countries. With the exception of Greece, all programs are part of university curricula. In Russia, logopedics training is offered both at universities and at higher pedagogical institutions.

\section{KARGER}

Fax +4161306 1234

E-Mail karger@karger.ch

www.karger.com
(C) 2010 S. Karger AG, Basel

$1021-7762 / 10 / 0625-0217 \$ 26.00 / 0$

Accessible online at: www.karger.com/fpl
Dr. Dobrinka Georgieva

Department of Logopedics, South-West University 66 Ivan Mihailov Street

BG-2700 Blagoevgrad (Bulgaria)

Tel. +359 7388 5504, Fax +359 7388 5516, E-Mail doby_logo@abv.bg 
Table 1. Characteristics of logopedics programs per country

\begin{tabular}{|c|c|c|c|c|c|}
\hline & Universities & Scientific staff & Length of course & $\begin{array}{l}\text { Qualification achieved on } \\
\text { graduation }\end{array}$ & $\begin{array}{l}\text { Number of } \\
\text { professionals trained }\end{array}$ \\
\hline Bulgaria & $\begin{array}{l}\text { South-West University } \\
\text { Sofia State University }\end{array}$ & $\begin{array}{l}2 \text { full professors } \\
6 \text { associate professors } \\
5 \mathrm{PhD}\end{array}$ & $\begin{array}{l}4 \text { years: Bachelor } \\
1 \text { year (after BA): Master } \\
3 \text { (4) years after Master: PhD } \\
2-2.5 \text { years for other } \\
\text { background: Bachelor }\end{array}$ & logopedist & $\begin{array}{l}1,000 \text { special } \\
\text { educators-logopedists } \\
300 \text { logopedists }\end{array}$ \\
\hline Greece & $\begin{array}{l}\text { TEI Patras } \\
\text { TEI Ioannina } \\
\text { TEI Kalamata }\end{array}$ & majority are $\mathrm{PhD}$ & 4 years: Bachelor & logopedist (logotherapist) & 900 \\
\hline Macedonia & $\begin{array}{l}\text { Skopje State } \\
\text { University }\end{array}$ & $2 \mathrm{PhD}$ & $\begin{array}{l}3 \text { years: Bachelor } \\
4 \text { years: Bachelor }\end{array}$ & $\begin{array}{l}\text { assistant logopedist } \\
\text { special educator (logopedist) }\end{array}$ & $\begin{array}{l}\text { first to graduate in } \\
2009\end{array}$ \\
\hline Poland & $\begin{array}{l}\text { Universities of Lublin, } \\
\text { Gdansk, Warsaw, Krakow, } \\
\text { Lodz, Bialystok, Wroclaw, } \\
\text { Szczecin, Katowice, } \\
\text { Olsztyn and Poznań }\end{array}$ & $\begin{array}{l}15 \text { full professors } \\
20+\text { associate } \\
\text { professors }\end{array}$ & $\begin{array}{l}3 \text { years: Bachelor } \\
2 \text { years: } \text { Master } \\
3 \text { years: } \mathrm{PhD}\end{array}$ & $\begin{array}{l}\text { logopedist } \\
\text { logopedist-audiologist } \\
\text { logopedist-neurologopedist }\end{array}$ & 5,000 \\
\hline Russia & $\begin{array}{l}60+ \\
\text { Moscow State Pedagogical } \\
\text { University is a leading } \\
\text { institution }\end{array}$ & $\begin{array}{l}28 \text { full professors } \\
\text { (only in Moscow) } \\
100+\text { associate professors } \\
100+\text { PhD }\end{array}$ & $\begin{array}{l}5 \text { years: } \text { Master } \\
3 \text { years: DPhil }\end{array}$ & $\begin{array}{l}\text { special educator } \\
\text { logopedist }\end{array}$ & 50,000 \\
\hline
\end{tabular}

TEI = Technological Educational Institution.

The education of logopedists in Bulgaria started in 1956 at Sofia University in the Faculty of Philosophy, and in 1986 at the South-West University (SWU) in Blagoevgrad as part of special education training programs (in defectology $y^{1}$ ). Logopedics diplomas were awarded to students with basic training as special education teachers/ pedagogues. In 2002, both universities implemented pure logopedics programs (apart from special education). The first department of logopedics in the country was founded in June 2002 at the SWU. In 2009, the Faculty of Public Health was established and accredited at the SWU and now organizes logopedics education at the university. In Bulgaria, the SWU and Sofia University both have undergraduate and graduate programs in 'pure' logopedics. Other Bulgarian state universities, e.g. Shumen, Plovdiv and Stara Zagora, offer a degree in special education with specialization in logopedics. The SWU program has a strong orientation toward the public health, while the

1 The popular term 'defectology', used in Russia and some East European countries, could be defined by the Latin term 'defectus' meaning 'disorder' and the Greek 'logos' as 'science of human disorders, impairments'. The education of students is divided into 4 main specialties: logopedics, pedagogy for mentally retarded persons, pedagogy for deaf and hearingimpaired persons, and pedagogy for blind persons. program at Sofia University has a special education orientation. In Bulgaria, both universities offering logopedics training have small speech therapy centers for student clinical practice within the university framework. The universities also use existing public and private logopedics clinics in educational and medical settings as training centers. According to the European Union Statistics Classification of 1999 (ISCED 97: field of education and training; area 72: health and social sciences; professional direction 726: physiotherapy and rehabilitation), logopedics (speech therapy) is considered a paramedical (health) profession. As a new member of the European Union, Bulgaria will undoubtedly adhere to these rules. In July 2009, the SWU logopedics program successfully completed the official procedure of accreditation and evaluation as part of the health sciences professions.

Speech therapy education in Greece started in 1996 at the Technological Educational Institution (TEI) in Patras. In the academic years 2009 and 2010, a new program in logopedics was introduced at the TEI in Kalamata. The programs in Greece are strongly oriented toward speech and language pathology and located in the health sciences area. In Greece, there is a logopedics center within the TEI of Patras. The department there intends to move to a newly renovated building with 11 classrooms and labora- 
Table 2. Qualification of logopedists in the different countries

\begin{tabular}{ll}
\hline & Qualification (degree/diploma) \\
\hline Bulgaria & - logopedics: diploma as a logopedist \\
& - special education: diploma as a special educator \\
& with specialization in logopedics \\
\hline Greece & - logotherapy: diploma as a logotherapist \\
& (speech-language pathologist) \\
\hline Macedonia & - logopedics: diploma as an assistant logopedist \\
& - special education: diploma as a special educator \\
& with specialization in logopedics \\
\hline Poland & - logopedics: diploma as a logopedist \\
& $-\begin{array}{l}\text { surdologopedics (pedagogy for the deaf): } \\
\text { diploma as a surdologopedist }\end{array}$ \\
\hline Russia & neurologopedics: diploma as a neurologopedist \\
\hline
\end{tabular}

tory space. They also have a free clinic with 6 individual therapy rooms, 1 group therapy room and 1 audiology screening room. The department collaborates with public and private clinics which allow students to complete their required 6-month practicum.

In Macedonia, logopedics education began in 2008 at Skopje State University in 2 faculties: the Faculty of Philosophy at the Institute for Special Education and Rehabilitation, and the Faculty of Medicine. The first provides training in defectology (similar to special education), while the second trains 'pure' speech-language pathologists. The logopedics programs in Macedonia train speech therapists/assistant logopedists.

Education in logopedics in Poland began in 1970 in Lublin, which has the largest center for logopedics studies in Poland at the Maria Curie Skłodowska University. Their Logopedics Department provides a 4-semester postgraduate program for special education teachers and for students from the Pedagogy Department. Since the inception of the program, there have been numerous changes in the organization of the educational programs and in the number of hours required. The majority of logopedics programs in Poland are pedagogically oriented. Only graduates from Lublin and Gdansk have qualifications as logopedists. Medical specializations such as neurologopedics and surdologopedics can only be obtained as part of a postgraduate program and an 11-month clinical practicum.

Education in logopedics in Russia has a long and strong tradition. Prior to 1925, the education of teachers working with people with disabilities was general and unspecialized. In 1946/1947, the first logopedics division within the framework of the Moscow State Pedagogical Institute was opened. In the Russian Federation, there are more than 60 logopedics training centers at universities and higher education institutions that specialize in pedagogy (full-time education in the Faculties of Defectology or special education). The Moscow State Pedagogical University is responsible for accrediting and evaluating other Russian universities and their branches of logopedics. Currently, special education in Russia is divided into 4 main specialties: pedagogy for the mentally retarded, pedagogy for the deaf and hearing-impaired, pedagogy for the blind, and logopedics. In Russia, one of the leading departments of logopedics training is the Department of Clinical, Psychological-Pedagogical, Psychophysiological and Linguistic Mechanisms of Speech Disorders at the Moscow State Pedagogical University. In Russia, the logopedics profile has an accent on special education. The qualification provided is as a teacher-pedagogue and special psychologist. Specialized methodological laboratories are available for student training. In Russia, the State Educational Standards for higher professional education are accepted for the logopedics specialty and are approved by the Ministry of Education and Science. Since 2007/ 2008, the Russians have published standards for higher professional education for bachelor's and master's degrees with a focus on logopedics. These are now in the process of being approved by the Ministry of Education and Science of the Russian Federation.

All of the programs are reported to cover the following content areas (providing more than an orientation): aphasiology, audiology, dysfluency, rehabilitation of children with mental handicaps, phonetics, phoniatrics, laryngectomy, child language disorders, linguistics, dyslexia/dysgraphia, neurology, orofacial disorders, pedagogy, psychology, voice disorders, multiple disorders and hearing impairments. Swallowing disorders are not covered in Bulgaria and Poland, and in Poland, voice disorders are covered only in postgraduate studies. In Bulgaria, the evidence-based practice topics are included as a part of the main logopedics courses, like fluency disorders and voice disorders [2]. The Russian logopedics curriculum also includes special national standards for student training in logopedics [3], which require 20 weeks of clinical practice.

Table 3 shows the specialized training provided at master's and doctoral levels. The master's (graduate) programs in all the countries usually require 1 or 2 years of study following the awarding of a bachelor's degree. The 
Table 3. Master and $\mathrm{PhD}$ programs per country

\begin{tabular}{|c|c|c|}
\hline & Master's degree & Doctoral degree \\
\hline Bulgaria & $\begin{array}{l}\text { - logopedic management of fluency and voice disorders } \\
\text { - logopedic management of cochlear implants } \\
\text { - general logopedics }\end{array}$ & $\begin{aligned} & \text { all types of communication disorders in: } \\
& \text { - } \text { special education area } \\
& \text { - psychology } \\
& \text { - social medicine and health sciences }\end{aligned}$ \\
\hline Greece & - 1 combined program: dyslexia and new technologies & $\begin{array}{l}\text { no; PhD studies in other countries or at medical } \\
\text { school in Greece }\end{array}$ \\
\hline Macedonia & no information & no information \\
\hline Poland & $\begin{array}{l}\text { - neurologopedics } \\
\text { - surdologopedics }\end{array}$ & $\begin{aligned} & \text { all types of communication disorders in: } \\
& \text { - linguistics } \\
& \text { - pedagogy } \\
& \text { - medical sciences }\end{aligned}$ \\
\hline Russia & - all communication disorders; special profile in logopedics & $\begin{array}{l}\text { - special education: logopedics } \\
\text { - medical sciences }\end{array}$ \\
\hline
\end{tabular}

programs focus on a specific discipline such as education, special education, or communication disorders and sciences. Where a PhD in Logopedics is offered, it usually requires 3-4 years of study after the master's degree in a particular discipline culminating in an original researchoriented dissertation.

In all the countries, clinical hours are carried out under the supervision of professional logopedists and observation is included as part of each of the logopedics courses. The focus is on the evaluation, diagnosis and clinical management of patients with communication disorders by students. They are conducted in logopedics rooms (units) in special schools, hospitals and mainstream schools.

Bulgaria, Greece, Macedonia and Poland have implemented the European Credit Transfer and Accumulation System (ECTS); Russia has not yet implemented the ECTS credit system but is in the process of gaining approval for doing so. The ECTS is a standard for comparing the study attainment and performance of students of higher education across the European Union and other collaborating European countries. For successfully completed studies, ECTS credits are awarded. One academic year corresponds to 60 ECTS credits, which is equivalent to $1,500-$ $1,800 \mathrm{~h}$ of study in all countries irrespective of the standard or qualification type. They are used to facilitate transfer and progression throughout the European Union. The ECTS will be complemented by the European Credit Transfer System for Vocational Education and Training, which the ministers responsible for vocational training in 32 European countries agreed to develop in the Maastricht Communiqué of December 14, 2004. In Bulgaria, the ECTS credit system was officially implemented by an act of the Ministry of Education and Science in 2003. There are no officially accepted credits for the $\mathrm{PhD}$ degree. The credit system is also used in Greece, Macedonia and Poland. Table 4 shows the course hours and credits, and the clinical observation and practical hours for each of the countries.

Bulgaria, Greece and Poland are involved in the European Union Erasmus Program; Macedonia and Russia are not. The Erasmus Program is a European student exchange program established in 1987. The aim of Erasmus is to encourage and support academic mobility of higher education students and teachers within the European Union. In Bulgaria, the SWU Department of Logopedics has bilateral Erasmus contracts dating from 2003 with: Gent University, Belgium; Ruhr University, Bochum, Germany; Lublin University, Poland; KATHO College, Kortrijk, Belgium; Montfort University, UK, and Eindhoven University, The Netherlands. The program is based on diverse themes related to communication disorders, but the priority is on fluency and voice. The Greeks have more than 8 years of experience with the Erasmus program in logopedics. Many centers in Poland cooperate with other countries in the field of logopedics by taking part in both Erasmus and other educational and scientific programs.

Most logopedists in the countries sampled work in educational settings: kindergartens, mainstream schools, 
Table 4. Supervised clinical practicum time during logopedics education

\begin{tabular}{|c|c|c|c|c|c|c|c|}
\hline Bulgaria & 3,000 & $\begin{array}{l}240 \text { ( } 30 \text { per } \\
\text { semester) }\end{array}$ & 675 & 250 & 700 & $\begin{array}{l}60 \text { (30 per } \\
\text { semester) }\end{array}$ & 250 \\
\hline Greece & 3,000 & 240 & $\begin{array}{l}900 \text { (incl. } \\
\text { observations) }\end{array}$ & & - & - & - \\
\hline Poland & 3,000 & 180 & not specified & $\begin{array}{l}\text { not specified, } \\
\text { but provided for } \\
\text { each course }\end{array}$ & & 120 & $\begin{array}{l}11 \text { months, } \\
100-150 \mathrm{~h} \\
+50 \mathrm{~h} \text { for neurologopedics } \\
\text { and surdologopedics }\end{array}$ \\
\hline
\end{tabular}

Russia provides master's programs for 5-year trainings. Russia is in the process of acceptance of the ECTS. Compared to the system of bachelor, master and $\mathrm{PhD}$, the degree in Russia could be termed a master's degree (higher education).

special schools and resource centers. In addition, many logopedists are employed by clinical organizations such as hospitals, rehabilitation centers, social daycare centers, etc. In some countries such as Bulgaria, Macedonia, and Poland, there are a few private logopedic practices, and these are not regulated by law.

In Bulgaria, 2 journals are published: the Bulgarian Journal of Communication Disorders (in English; since 2006) and the Journal of Special Education (in Bulgarian; since 1995). The main goal of these journals is to enhance scientific production and to popularize Bulgarian logopedics abroad. There are no specialized journals for logotherapy based in Greece or Macedonia. The Institute for Special Education and Rehabilitation at Skopje State University publishes the Journal of Special Education and Rehabilitation in Macedonian and English. Polish specialized logopedics journals have been published by the Polskie Towarzystwo Logopedyczne (Polish Logopedics Society) and Marie Curie Skłodowska University in Lublin since 1960. These are Logopedia (since 1960) and Biuletyn logopedyczny (since 1999). Additionally, since 1989, the Polski Komitet Audiifonologii (Polish Audiophonology Committee) and Polskie Towarzystwo Zaburzeń Głosu (Polish Society of Speech, Hearing and Language Communication Disorders) have published Audiofonologię. Two journals are produced in Russia: Logopaedics Today (Логопедия сегодня) and Logopedists (Логопед).

\section{Conclusion}

Recent members of the European Union are working to organize their higher education systems in logopedics in accordance with the Comité Permanent de Liaison des Orthophonistes/Logopèdes (CPLOL) [4] and the International Association of Logopedics and Phoniatrics (IALP) [5] standards. Along with Greece, they have applied for a few European Union educational and research projects to harmonize their curricula and programs. Macedonia is also making its first steps in this area. Greece has a track record of more than 13 years in successfully training students in logopedics. Russia clearly has developed a new model for training professionals in the assessment and treatment of human communication disorders. Today, Russia occupies one of the top places in Europe in terms of the number of speech-language pathologists (more than 55,000). All the countries represented in this short overview need to improve the quality of their programs and to guarantee the excellence of their professional education. They need to:

- create and mandate continuing education programs, workshops and seminars for logopedists;

- extend the traditional role of the logopedist as educator and to develop new communication disorder specializations;

- balance the 3 sciences in logopedics curricula, i.e. language, behavioral and biomedical sciences; 
- put a special accent and emphasis on cluttering, dysphagia and swallowing disorders, and pay more attention to cultural and linguistic diversity, especially in Bulgaria, Poland and Macedonia;

- conduct research projects consistent with the 7th European Union Framework Program;

- promote and increase the participation in educational Erasmus and Erasmus Mundus Programs for master's and/or doctoral degrees.

The national associations of logopedists in these countries should establish or renew their standards for student education, combining academic and clinical knowledge. The logopedics profession must be regulated. New areas of clinical communication disorders must be fully and properly covered by health or social insurance companies. It is obvious that new educational and research infrastructure needs to be established and comply with European and international standards. In order to meet the 1995 and the new 2010 IALP guidelines for initial student training in logopedics [5], a reevaluation and amendments are strongly recommended. In conclusion, we believe these recommendations and revisions will ultimately help improve the quality of student education in logopedics.

\section{Acknowledgments}

The author gratefully acknowledges the help of Assist. Prof. Illias Papathanasiou and Assist. Prof. Voula Georgopoulos (TEI Patras, Greece), Prof. Tomash Wosnjak (Maria Curie Skłodowska University, Lublin, Poland) and Assoc. Prof. Yulia Filatova (Moscow State Pedagogical University, Russia) and Assoc. Prof. Vladimir Traykovski (Skopje State University, Macedonia) for providing necessary information.

The author acknowledges the help of Dr. William Clark for suggestions and assistance in writing this article in English.

\section{Appendix: Questionnaire}

1 How many education centers for logopedics are there in your country? Please, briefly describe them.

2 Do they lead to the same kind of qualification (degree/diplo$\mathrm{ma})$ ?

3 When did education in logopedics start in your country? Brief description.

4 Are the education and training centers part of universities?

5 How long (in years) are the programs?

6 Who is the main employer of qualified logopedists (schools, hospitals)? Other?

7 How many students have qualified in your country since the start?

8 Which areas are covered within the program (more than only orientation: aphasiology, audiology, cleft palate, dysarthria, dysphagia, dysfluency, rehabilitation of children with mental handicaps, phonetics, phoniatrics, psychiatry, laryngectomy, child language disorders, linguistics, dyslexia/dysgraphia, neurology, orofacial disorders, pedagogy, psychology, voice disorders, multiple disorders, hearing impairments)? Could you provide a short version of the educational curriculum? Is the evidence-based practice module included in your curriculum in logopedics?

9 Do the education programs have specific profiles?

10 Are there specialization programs available (postgraduate level)?

11 Are there doctorate programs in logopedics? If not, what are the possibilities for a speech therapist to become a $\mathrm{PhD}$ ?

12 How many hours (estimate) of supervised clinical practicum does the student have during his/her education in logopedics? How many hours of observations?

13 Do you have a logopedics clinic/center within the university frame?

14 Did you implement the ECTS in the student training? How many credits do your logopedics bachelor, master and $\mathrm{PhD}$ programs consist of?

15 Are you involved in the European Union Erasmus Program in logopedics? How many years of experience do you have?

16 How many university professors teach logopedics in your country?

17 Do you have a specialized logopedics journal in your country?

\section{References}

3 Beljakova LI, Babina GV: Student's Handbook for Self-Work in Logopedics Specialty 031800, Located in the Defectology Faculty (in Russian). Moscow, Prometei, 2004.

4 Standing Liaison Committee of Speech and Language Therapists or Logopedists of the European Union: CPLOL, 1988-1998: 10 years of activities. Paris, Standing Liaison Committee of Speech and Language Therapists or Logopedists of European Union, 1998, pp 13-45.

5 IALP guidelines for initial education in logopedics (speech/language pathology/therapy, orthophony, etc.). Folia Phoniatr Logop 1995;47:296-301. 